\title{
An environmental oriented model for optimum cut off grades in open pit mining projects to minimize acid mine drainage
}

\author{
${ }^{1 *}$ F. Rashidinejad; ${ }^{1,2}$ M. Osanloo; ${ }^{1,2}$ B. Rezai \\ ${ }^{1}$ Department of Mining Engineering, School of Engineering, Sciences and Research Campus, \\ IAU, Tehran, Iran \\ ${ }^{2}$ Department of Mining, Metallurgical and Petroleum Engineering, Amirkabir University of Technology, \\ Tehran, Iran
}

Received 29 January 2008; revised 19 February 2008; accepted 3 March 2008; available online 10 March 2008

\begin{abstract}
Environmental concerns on mining activities started near the end of the $20^{\text {th }}$ century and is still underway. Due to mining activities, the adverse environmental impact has been significant throughout the history of mankind, whereas the minerals produced by mining activities have been providing the basis for human civilization. The legacy of past mining practices is large quantities of acid generating waste materials and tailings that caused abounding acid mine drainage problems. Modern mining environmental management tends to focus on concerns over the impact of waste disposal on surface primarily in the form of tailings and waste materials structures. Sustainable development principles are being increasingly applied by mining companies in developed and developing countries. Operating costs per unit of operation is recognized to be one the most important sustainable mining practice indicator and cut off grade is considered to be a well-founded representative for this indicator. In this paper, a developed model for optimum cut off grades is presented that not only relies on economical aspects but also minimizes adverse environmental impact in the form of acid mine drainage elimination or mitigation against the approach of postponing the restoration/reclamation activities at the end of the project's life.
\end{abstract}

Key words: Acid generating materials, environmental impact assessment, sustainable development, tailings, waste management

\section{INTRODUCTION}

In 1987, sustainable development has first been defined by the World Commission on Environment Development (WCED) in the so-called Burntland report as a development that "meets the needs of the present without compromising the ability of the future generation to meet their own needs". The concept requires the integration of economic, environmental and social considerations into all decision makings, fostering intra-generational equity through the alleviation of poverty by concentrating the benefits of development in lesser developed areas and considering the needs of the future generation to ensure that intergenerated equity exists. A prerequisite of sustainable development must to be ensures uncontaminated streams, rivers, lakes and oceans. There is growing awareness on the environmental legacy of mining activities which have been undertaken with little concern for the environment. The price paid for

*Corresponding Author Email: farshidnejad@hotmail.com Tel.: +9821 4481 7164, Fax: +9821 44817194 human's everyday use of minerals has sometimes been very high. Mining by its nature can consume, divert and seriously pollute water resources. Changes in laws, technologies and attitudes have begun to address some of the most immediate threats posed by mineral development, but there are still many areas of mining practices and regulations that need to be addressed. Despite undesirable outcomes in the past, the mine design process continues to focus on technical mining and financial considerations with environmental and social objectives considered later in the design sequence, unfortunately more often in the form of impact mitigation (Odell and Scoble, 2005). Two great revolutions in mining occurred during the $20^{\text {th }}$ century. The first took place almost 100 years ago (1903-1905) with Daniel Jackling's experiment in the economies of scale for large-scale mining at Bingham Canyon. Jackling's idea changed the focus of base metal exploration toward lower-grade, high-tonnage deposits. The second revolution was the impact of environmental 
and social concerns on mining. It started at the end of the $20^{\text {th }}$ century and is still underway (Hitzman, 2005).

One of the objectives of a mining operation is to maximize the net present value (NPV) of the project (Wheeler and Rodrigues, 2002 and Ding et al., 2007). Open pit mine designs which maximize the NPV without the environmental consideration during planning are not really an optimum design. Actually, such designs are mutually exclusive with the objectives of sustainable development. Fortunately, sustainable development principles are being increasingly applied by mining companies in developed and developing countries. Mining systems need to be reengineered, based on a new paradigm that mining is a business whose success fundamentally depends on waste management. Environmental protection has the highest priority in modern mining. Common concerns in a mining operation associated with the environment may include land and surficial materials pollution on the mine site and groundwater contamination in the vicinity by the waste materials and tailings. Some of these materials may be acid generating and they have to be managed properly to protect the environment. Environmental aspects of pre-defined mining projects are mostly identified by Environmental Impact Assessment (EIA). In international terms, surface mining operations, particularly those entailing reservoir and tailings dams, are considered as the activities with the highest possible environmental risk, demanding the most detailed and rigorous EIA (Rashidinejad, 2004).

Mining design and planning is a very complex engineering subject and requires engineering knowledge and a good understanding of various scientific disciplines. One of the most important issues is the cut off grade which is simply a grade used to assign a destination label to a parcel of material (Hustrulid and Kuchta, 1995). This parameter, which is the criterion normally used in mining to discriminate between ore and waste materials in the body of a deposit, extensively affects the size and the life of deposits (Camus, 2002). All mineral deposits are made up of mixtures of ore and waste rock (Zhang, 1998). Waste materials may either be left in place or sent to waste dump. Ore is sent to the treatment plant for further processing and eventual sale. For a single-mineral deposit, lower cut off grade causes higher amounts of ore to be processed and subsequently higher tailings and lower amounts of waste materials to be dumped resulted in fluctuations in the cash flow of a mining project (Osanloo and Ataei, 2003). Operating costs per unit of operation is recognized to be one of the most important sustainable mining practice indicators and cut off grade is considered to be a well-founded representative of this indicator (James, 1999). There is a balance between the cut off grade and environmental strategies. In practice, achieving the balance is the real challenge. The fact that the calculation of optimum cut off grades can neither be determined nor measured precisely with a single parameter further complicates the problem (Rashidinejad et al., 2007).

\section{MATERIALS AND METHODS}

One of the open pit mining problems is that this type of surface mining has become more mechanized and therefore able to handle more rock and ore material than ever before. Consequently, mine waste has been enormously multiplied. As mine technologies are developed to make it more profitable to mine low-grade ore, even more waste will be generated in the future. This trend requires the mining industry to adopt and consistently apply practices that minimize the environmental impacts of this waste production. These mining wastes must be properly managed (Rashidinejad and Raouf Sheibani, 2004). Waste management practices can take place as the following options with declining superiority (Parsons and Hume, 1997):

- Waste avoidance, i.e. practices that prevent the production of waste;

- Waste reduction, i.e. practices that reduce waste;

- Waste re-use, i.e. direct re-use of waste materials;

- Waste recycling or reclamation, i.e. using components of waste in other processes;

- Waste treatment, i.e. to reduce hazard, usually at the site of generation;

- Waste disposal.

Mining companies use the last three options extensively. Other industries, notably the chemical industry, have made use of the first three options by modifying or changing processes. The problem with application of the first three options to mining wastes is that in the current mining paradigm, as ore grade become lower resulted in extra wastes to be produced. The paradigm has been proposed that "mining companies are waste management companies" and sustainable development principles being increasingly applied by these companies. Strategies are available 
to shift this paradigm and to minimize the surface impact of waste disposal. Firstly, mining methods need to be developed which are more selective, i.e. leave waste in place. The eventual, more futuristic outcome of this strategy may well be the implement of in-situ or solution mining. The adoption of pre-concentration and even the full integration of mineral processing within the mine workings could be important in this strategy in the interim. Secondly, technologies should be further pursed which enable the return of waste securely to the void.

In underground mines, there is at least the opportunity to dispose the waste back in the mined voids during the life cycle of the mine. They may also be the case in open cast or strip mining on surface, but in open pit mines this is only the case at the end of the mining operation. Many of the older open pits are now looking to continue as underground operations. This is possible only where low-cost, bulk mining is feasible generally through caving methods. Unfortunately, such methods do not facilitate the underground disposal of waste (Scoble et al., 2000).

Besides, orebodies are becoming harder to find, more difficult in nature and tend to be deeper and of lower grade, i.e. the head grades are in decline. They are becoming less accessible, more difficult to process and thus more capital intensive. The technical and economic challenges are increasing (Cross, 2005). Fig.
1 shows the copper industry ore grade during 1770 2007. Acid generating nature of the ore and the host rock are the most important information among the structural (physical and chemical) information (Lee Bullock, 2001). The chemical weathering of an individual mineral within a polymineralic aggregate can be classified as an acid producing, i.e. generation of $\mathrm{H}^{+}$, acid buffering, i.e. consumption of $\mathrm{H}^{+}$, or non-acid generating/consuming reaction, i.e. no generation or consumption of $\mathrm{H}^{+}$. For example, the degradation of pyrite is an acid producing reaction, whereas the weathering of calcite is acid buffering, and the dissolution of quartz does not consume or generate any acid (Lottermoser, 2003). The balance of all chemical reactions occurring within a particular material must be determined. Acid Base Accounting (ABA) and Net Acid Generation (NAG) are most commonly used methods for evaluation of Acid Mine Drainage (AMD) production.

AMD is a serious water pollution problem, for its contaminants will eventually affect the quality of the receiving streams (Ricca and Chow, 1974; Deissmann et al., 2000). Important features of state reclamation laws (as noted by National Research Council-NRC) include requirements relating to characterization of overburden and ores, prediction of acid drainage and management of acid generating materials (Parameswaran, 2005).

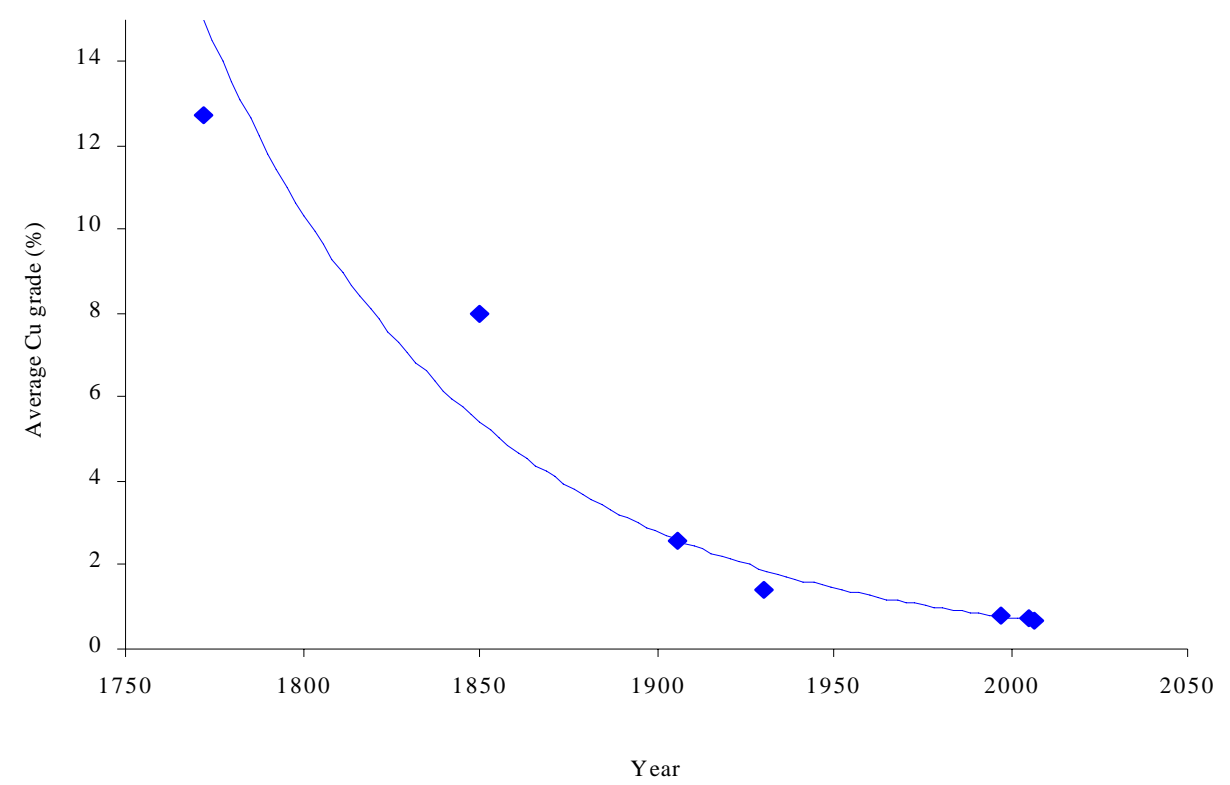

Fig. 1: Copper industry ore grade during $1770-2007$ 
The legacy of past mining practices is large quantities of acid generating waste materials and tailings. In 1995, estimated acid producing and potentially acid producing mine wastes in Canada were 1877.7 Mt of tailings and 738.9 Mt of waste materials. The corresponding estimates of acid producing liability were $\$ 1.52 \mathrm{~b}$ and $\$ 0.40 \mathrm{~b}$, respectively. Although grossly over-simplified, these translate into costs of $0.81 \$ / t$ acid generating tailings and $0.54 \$ / t$ acid generating waste materials. The cost/ton values are significantly under-estimated, as the estimated liability does not include waste/tailings placed underwater.

A prediction on acid generation should begin well prior to the production of sulfidic wastes at mine sites.
Preliminary evaluations can be performed as early as the exploration drilling and early mining of an orebody. Fundamental basic data for waste characterization and acid generation production include: existing lithologies, structural features, ore and gaunge textures and mineralogy, particle size distribution, depth of oxidation, and whole rock geochemistry. Geological data such as pyrite content, geochemical analysis $\left(\mathrm{S}, \mathrm{C}, \mathrm{CO}_{3}\right.$ and metals), and static test data can be used to construct a three-dimensional block model of different waste materials units prior to mining. Mining companies routinely utilized several hundred ore assay samples to model the orebody, but often relied on only a handful of whole rock analyses to project the geochemistry of the waste rock (Shay and Cellan, 2000).

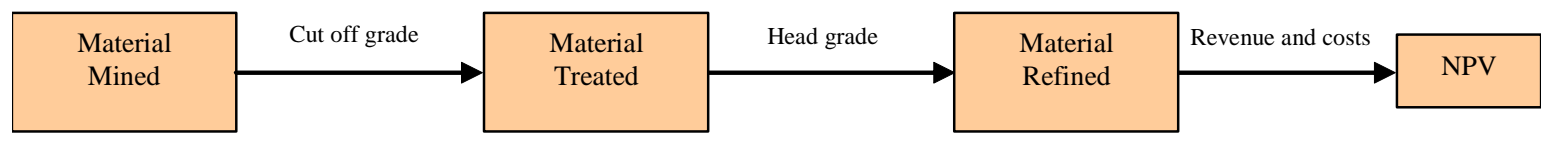

Fig. 2: Relationship between material mined, treated mineral, material refined and NPV

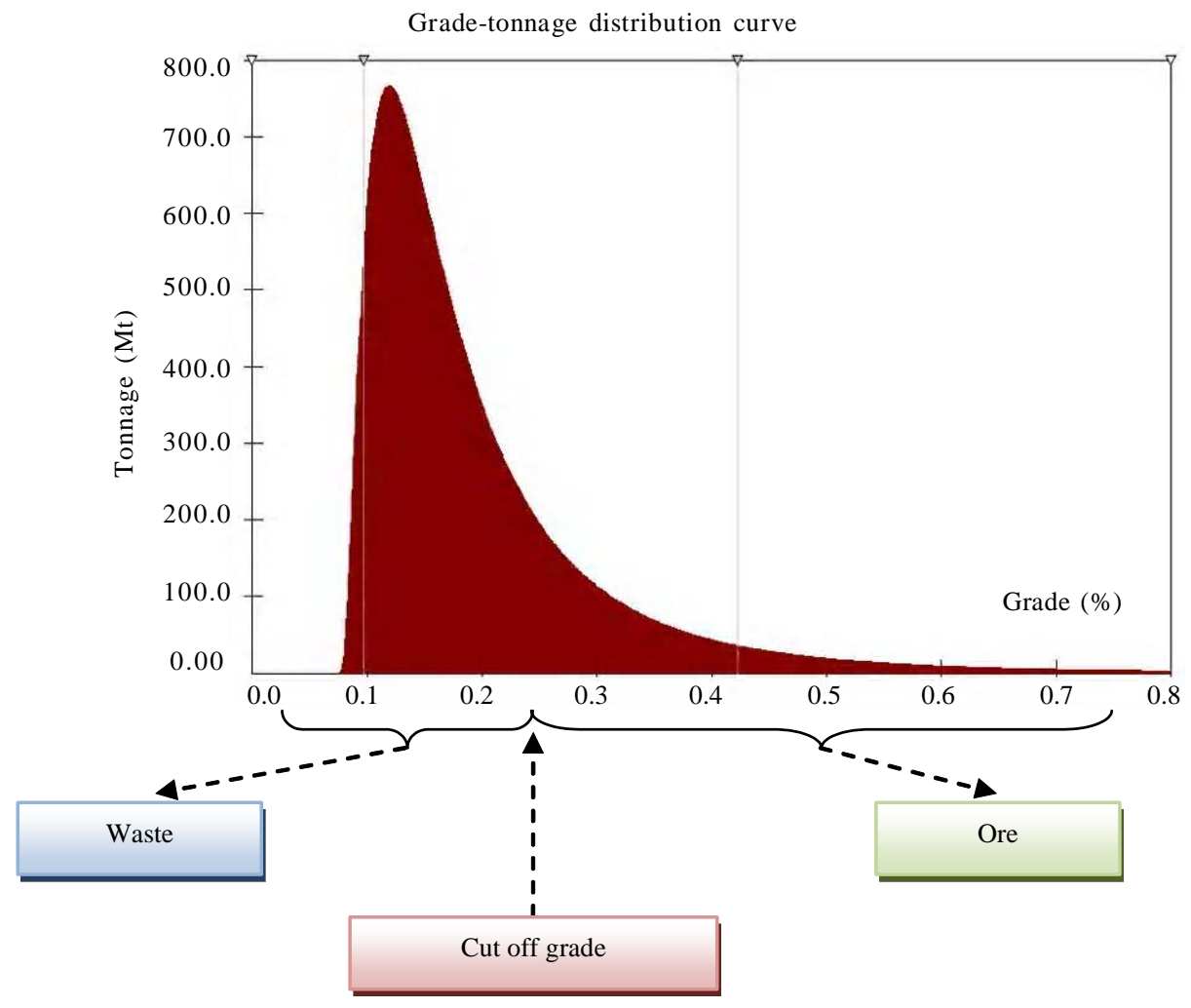

Fig. 3: Cut off grade determinations within a given orebody 
The acid generating rock can be either placed in a dump with bedded layers of alkaline material or blended with the alkaline material.

The best environmental controls, and least expensive in the long run, are waste management practices that focus on "prevention" rather than "treatment". Prevention refers to strategies which include the application of lime exposed surfaces as well as the application of bactericides to prevent the growth of thiobacllus ferro-oxidants. There are also nonchemical proactive treatments such as coverage or encapsulation of waste materials and tailings. Treatment refers to AMD liquid collection and neutralization. The treatment could be chemical (dosing with $\mathrm{NaOH}$ ) or biological (wetlands).

For selective flotation of base metal sulfides, lime is added to depress pyrite and pyrrhotite. The addition of lime contributes to the alkalinity of the tailings. Based on sulfide mineral contents of the tailings, more lime may be added to reduce the acid generating potential.

Sulfide removal from tailings allows for several disposal options. The isolated sulfide material can be stored below the surface of the tailings to limit the potential for oxidation. Alternatively, separate underwater disposal in a lined containment has been proposed.

At several existing plants, high sulfide cleaner flotation tailings are often combined with low sulfide scavenger tailings. In this case, the high sulfide cleaner tailings can be isolated for disposal by installing a separate pumping system. Such steps can subsequently reduce the acid generating potential of the bulk of the tailings material.

As discussed previously, NPV maximization is the most frequently adopted technique in the mining industry to determine the different parameters of the mining operation, such as cut off grade. The NPV value of the mining project is the total of annual cash flow of each production year discounted to the present time. Cut off grade is defined as the grade which discriminates between ore and waste within a given orebody, i.e. this parameter determines what is going to be ore which must be sent to run-of-mine stockpile or treatment plant and what is going to be waste which must be sent to waste dump pile. In concept, the economic value of a ton of ore must be greater than the cumulative costs associated with the mining and processing of that ton of ore, plus any other costs associated with the stripping and disposal of perhaps several tons of waste per ton of ore (Krige, 1987 \& Ersan et al., 2003). Fig. 2 shows the relationship between material mined, mineral treated, material refined and NPV. The lower the grade or the poorer the quality of ore, the higher will be the costs of recovery of the valuable products. The quality of ore is measured by many different factors, typically the ore grade and its distribution, orebody continuity, the workability of natural deposition of the mineralized bodies, and the ore treatability. Looking at the grade-tonnage distribution curve, it is obvious that, for any deposit, the tonnage and average grade always go in inverse direction - the higher the tonnage, the lower the average grade. Given the orebody, each cut off grade gives a unique set of tonnage and average grade, and hence the amount of mineral products that can be recovered. Fig. 3 shows the cut off grade determinations within a given orebody. The grade-tonnage distribution curve shown in this figure is assumed to be Lognormal as is in many ore deposits.

Cut off grade optimization in each mining operation implies definition for a cut off grade strategy or policy that yields the maximum expected NPV of the mining project. The term "expected" is important because mining companies do not know today how much they will be able to sell tomorrow, let alone next month or even next year. For mining companies to make decisions these uncertainties mean that they must guess, estimate, calculate, and consider contingencies. This process includes estimating cost functions for both short and long term. To estimate these functions, production costs must be classified as either fixed or variable. In the short run, both variable and fixed costs are often incurred; in the long run, all costs are variable. A sharp distinction between fixed and variable costs is not always possible or realistic.

This is a fact that the capacities of the equipment and the installations do not often permit much flexibility and therefore cut off grades can only be varied within narrow limits. In contrast, when expansion schemes are being designed and even more so when totally new mines are being developed, the theory can indicate cut off grades quite different from conventional policies with very substantial corresponding improvements in the overall returns. As NPV maximization related to many factors, usually only the variable that are to be determined by NPV maximization problem are thought to be variable, whereas the other variables are assumed to be fixed throughout the mine life. 


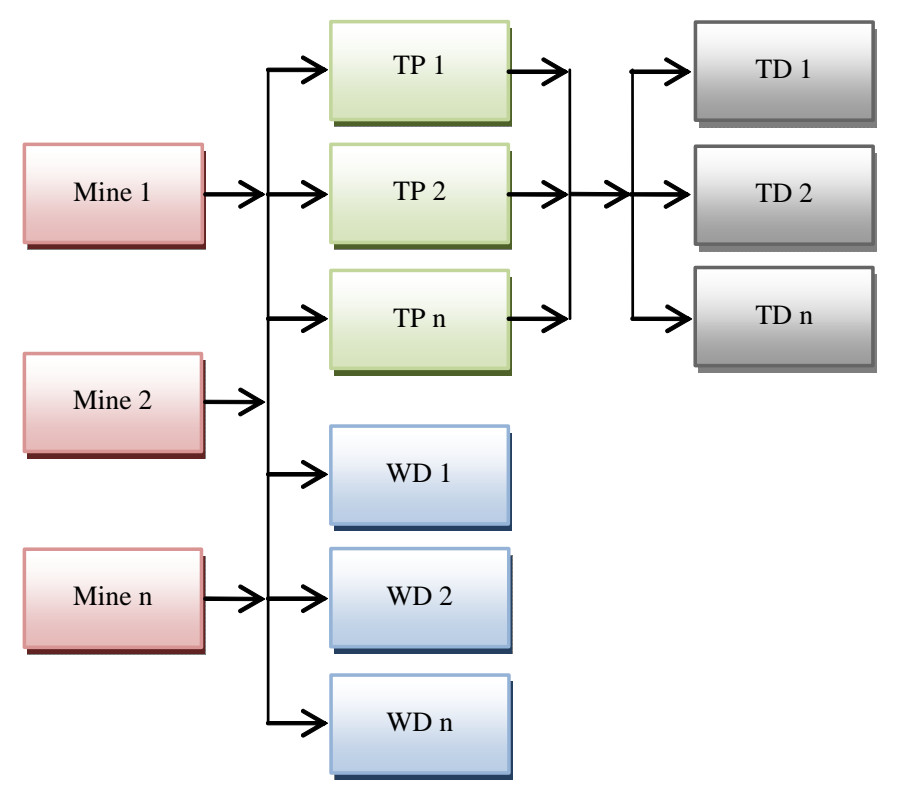

Fig. 4: Schematic representation of various material destinations (TP: Treatment Plant; TD: Tailings Dam; WD: Waste Dump)

Table 1: The notations of the model

\begin{tabular}{|c|c|c|c|}
\hline Notation & Explanation & Unit & Remarks \\
\hline $\mathrm{i}$ & Year indicator & - & \\
\hline $\mathrm{N}$ & Mine life & Years & \\
\hline S & Commodity price & $\$ /$ ton of product & \\
\hline M & Mine throughput & Tons/year & \\
\hline $\mathrm{C}$ & Treatment plant throughput & Tons/year & \\
\hline $\mathrm{R}$ & Refinery throughput & Tons/year & \\
\hline $\mathrm{m}$ & Mining operating costs & $\$ /$ ton of material & Ore + Waste \\
\hline a & ${ }^{* *} \mathrm{NA}$ waste disposal operating costs & \$/ton of waste & WD1 \\
\hline b & "AP waste disposal operating costs & $\$ /$ ton of waste & WD2 \\
\hline c & Treating operating costs & $\$ /$ ton of ore & \\
\hline u & NA tailings disposal costs & \$/ton of tailings & TD1 \\
\hline $\mathrm{v}$ & AP tailings disposal costs & $\$ /$ ton of tailings & TD2 \\
\hline r & Refinery/Sales/Overhead costs & $\$ /$ ton of product & \\
\hline $\mathrm{f}$ & Fixed or Time costs & \$/year & \\
\hline $\mathrm{g}$ & Average grade & $\%$ & \\
\hline $\mathrm{y}$ & Metallurgical recovery & $\%$ & \\
\hline $\mathrm{d}$ & Discount rate & $\%$ & \\
\hline$v$ & Incremental present value & \$/year & \\
\hline Qm & Material mined & Tons/year & \\
\hline Qc & Material Treated & Tons/year & \\
\hline $\mathrm{Qr}$ & Material refined & Tons/year & \\
\hline A & NA material mined and send to WD1 & $\%$ & \\
\hline B & AP material mined and send to WD2 & $\%$ & \\
\hline $\mathrm{U}$ & NA tailings send to TD1 & $\%$ & \\
\hline $\mathrm{V}$ & AP tailings send to TD2 & $\%$ & \\
\hline
\end{tabular}

*AP: Acid producing, ${ }^{* * N A}$ : Non-acid generating 
Lane formulated the optimum cut off grades through considering of opportunity cost of not receiving the future cash flows earlier during the mine life due to limiting capacities of any of mining, treating, or refining stages (Lane, 1964 and 1988). The cut off grades particularly in irregular deposits decline as the mine ages, because the older the mine, the smaller will the opportunity cost be (Baird and Satchwell, 2001; Minnitt, 2003 and Asad, 2005). The procedure for calculation of optimum cut off grades by Lane's method relies not only on economical factors but also on the size of the installations. The implementation of the Lane's method is possible in situation where ore reserves block model has been developed, and subsequently, the ultimate pit limit (UPL) is completed. In addition to the grade-tonnage distribution in the deposit, the parameters including mining, treating, and refining stage capacities, operating costs of these stages, and current commodity price are assumed to be known. The Lane's model maximizes the NPV of a mining project if it is accepted that all constraints have been considered in the model and influenced on it. There are many shortcomings to the Lane's cut off grade optimization approach (Dagdelen, Kawahta, 2007) but it is still the most commonly used method worldwide for cut off grade optimization. This model is ore-oriented and does not consider the costs related to waste materials.

To gain sustainable results from mining projects, holistic design criteria must be integrated in the design process. The best practice is to consider environmental mine-waste management requirements to eliminate or mitigate the mining residual and pollution in the original place. Fig. 4 shows the schematic representation of various material destinations from " $n$ " mines to " $n$ " treatment plant and " $n$ " waste dumps. The produced tailings of the treatment plants send to " $n$ " tailings dams. To simplify the modeling, one mine with two waste dumps, and one treatment plant with two tailings dams is considered. WD1 and WD2 are designated for the dumping of non-acid generating and acid producing materials, respectively. Some mitigation is required for WD2 and the related operating costs must be determined based upon the detailed design. In some special cases, it may be feasible to mix acid producing and acid buffering materials together in specific proportion to prevent AMD. In similar logic, TD1 and TD2 are designated for disposing of non-acid generating and acid producing tailings, respectively. Separation of tailings in the standpoint of acid generation characteristics is not well established in the mining industry, but it is along the sustainable mining practice and is a cost effective and reasonable solution for reducing acid generation tailings. The following notations are established to explain of the holistic cut off grade model (Table 1). The objective function of the problem is to maximize the Incremental present value which can be represented mathematically as follows:

Max NPV $=\left(\sum_{i=1}^{N} \frac{v_{i}^{*}}{(1+d)^{i}}\right)$

Where;

$$
\begin{aligned}
& v_{i}^{*}=\left(S_{i}-r_{i}\right) \times Q r_{i}-m_{i} \times Q m_{i}-a_{i} \times A_{i} \times\left(Q m_{i}-Q c_{i}\right) \\
& -b_{i} \times B_{i} \times\left(Q m_{i}-Q c_{i}\right)-c_{i} \times Q c_{i}-u_{i} \times U_{i} \times\left(Q c_{i}-Q r_{i}\right) \\
& -v_{i} \times V_{i} \times\left(Q c_{i}-Q r_{i}\right)-\left(f+d \times N P V_{i}\right) \times T
\end{aligned}
$$

or;

$v_{i}^{*}=\left(S_{i}-r_{i}+u_{i} U_{i}+v_{i} V_{i}\right) \times Q_{i}-\left(m_{i}+a_{i} A_{i}+b_{i} B_{i}\right) \times Q m_{i}$ $-\left(c_{i}-a_{i} A_{i}-b_{i} B_{i}+u_{i} U_{i}+v_{i} V_{i}\right) \times Q c_{i}-\left(f+d \times N P V_{i}\right) \times T$

The following constraints are evident:

$$
\begin{aligned}
& \mathrm{Qm}_{\mathrm{i}} \leq \mathrm{M} \text { for } \mathrm{i}=1, \ldots, \mathrm{N} \\
& \mathrm{Qc}_{\mathrm{i}} \leq \mathrm{C} \text { for } \mathrm{i}=1, \ldots, \mathrm{N} \\
& \mathrm{Qr}_{\mathrm{i}} \leq \mathrm{R} \text { for } \mathrm{i}=1, \ldots, \mathrm{N} \\
& \mathrm{Qr}_{\mathrm{i}}=\overline{\mathrm{g}} \times \mathrm{y} \times \mathrm{Qc}_{\mathrm{i}}
\end{aligned}
$$$$
\mathrm{A}_{\mathrm{i}}+\mathrm{B}_{\mathrm{i}}=1 \text { and } \mathrm{U}_{\mathrm{i}}+\mathrm{V}_{\mathrm{i}}=1
$$

Limiting economic cut-off grades may be limited individually by mine, treatment plant or refinery throughputs. If mine throughput is the governing limitation, the optimum cut off grade is given by:

$g_{m}=\frac{c_{i}-a_{i} A_{i}-b_{i} B_{i}+u_{i} U_{i}+v_{i} V_{i}}{\left(S_{i}-r_{i}+u_{i} U_{i}+v_{i} V_{i}\right) \times y}$

If treatment plant throughput is the governing limitation, the optimum cut off grade is given by:

$g_{c}=\frac{c_{i}-a_{i} A_{i}-b_{i} B_{i}+u_{i} U_{i}+v_{i} V_{i}+\frac{f+d \times N P V_{i}}{c}}{\left(S_{i}-r_{i}+u_{i} U_{i}+v_{i} V_{i}\right) \times y}$

If refinery throughput is the governing limitation, the optimum cut-off grade is given by:

$g_{r}=\frac{c_{i}-a_{i} A_{i i}-b_{i} B_{i}+u_{i} U_{i}+v_{i} V_{i}}{\left(S_{i}-r_{i}+u_{i} U_{i}+v_{i} V_{i}-\frac{f+d \times N P V_{i}}{R}\right) \times y}$ 
where $\mathrm{NPV}_{\mathrm{i}}$ obtained from the following equation:

$$
\operatorname{NPV}_{\mathrm{i}}=\frac{v_{\mathrm{i}}^{*} \times\left((1+\mathrm{d})^{\mathrm{N}}-1\right)}{\mathrm{d} \times(1+\mathrm{d})^{\mathrm{N}}}
$$

In any mining operation, the optimum cut off grade will never be less than $g_{m}$, since it is the break-even cut off grade.

If two components are to be simultaneously in balance, i.e. operating at full capacity, three cases are raised. The first balancing cut off grade $\left(\mathrm{g}_{\mathrm{mc}}\right)$ is the cut off grade that comes from Equation (8):

$\frac{\mathrm{Qm}_{\mathrm{i}}}{\mathrm{M}}=\frac{\mathrm{Qc}_{\mathrm{i}}}{\mathrm{C}}$

The effective optimum cut-off grade satisfying mine and treatment plant $\left(\mathrm{G}_{\mathrm{mc}}\right)$ is:

$\mathrm{G}_{\mathrm{mc}}=\mathrm{g}_{\mathrm{m}} \quad$ if $\mathrm{g}_{\mathrm{mc}} \leq \mathrm{g}_{\mathrm{m}}$

$\mathrm{G}_{\mathrm{mc}}=\mathrm{g}_{\mathrm{c}}$ if $\mathrm{g}_{\mathrm{mc}} \geq \mathrm{g}_{\mathrm{c}}$

$\mathrm{G}_{\mathrm{mc}}=\mathrm{g}_{\mathrm{mc}}$ otherwise

or $\mathrm{G}_{\mathrm{mc}}=$ Median value among $\mathrm{g}_{\mathrm{m}}, \mathrm{g}_{\mathrm{c}}$ and $\mathrm{g}_{\mathrm{mc}}$ The second balancing cut off grade $\left(g_{r c}\right)$ is the cut off grade that comes from Equation (9):

$$
\frac{\mathrm{Qc}_{\mathrm{i}}}{\mathrm{C}}=\frac{\mathrm{Qr}_{\mathrm{i}}}{\mathrm{R}}
$$

The effective optimum cut off grade satisfying treatment plant and refinery $\left(\mathrm{G}_{\mathrm{rc}}\right)$ is:

$\mathrm{G}_{\mathrm{rc}}=\mathrm{g}_{\mathrm{r}}$ if $\mathrm{g}_{\mathrm{rc}} \leq \mathrm{g}_{\mathrm{r}}$

$\mathrm{G}_{\mathrm{rc}}=\mathrm{g}_{\mathrm{c}}$ if $\mathrm{g}_{\mathrm{rc}} \geq \mathrm{g}_{\mathrm{c}}$

$\mathrm{G}_{\mathrm{rc}}=\mathrm{g}_{\mathrm{rc}}$ otherwise

or $\mathrm{G}_{\mathrm{rc}}=$ Median value among $\mathrm{g}_{\mathrm{c}}, \mathrm{g}_{\mathrm{r}}$ and $\mathrm{g}_{\mathrm{rc}}$

The third balancing cut off grade $\left(\mathrm{g}_{\mathrm{m}}\right)$ is the cut-off grade that comes from Equation (10):

$$
\frac{\mathrm{Qm}_{\mathrm{i}}}{\mathrm{M}}=\frac{\mathrm{Qr}_{\mathrm{i}}}{\mathrm{R}}
$$

The effective optimum cut off grade satisfying mine and refinery $\left(\mathrm{G}_{\mathrm{mr}}\right)$ is:

$$
\begin{aligned}
& G_{m r}=g_{m} \quad \text { if } g_{m r} \leq g_{m} \\
& G_{m r}=g_{r} \quad \text { if } g_{m r} \geq g_{r} \\
& G_{m r}=g_{m r} \quad \text { otherwise }
\end{aligned}
$$

Or $\mathrm{G}_{\mathrm{mr}}=$ Median value among $\mathrm{g}_{\mathrm{m}}, \mathrm{g}_{\mathrm{r}}$ and $\mathrm{g}_{\mathrm{mr}}$

The overall effective optimum cut-off grade $\left(G_{\text {opt }}\right)$ is middle value among $G_{m c}, G_{r c}$ and $G_{m r}$. The iterative stepsof optimization given in the algorithm are calculation intensive and time consuming, thus an Excel spreadsheet was developed to facilitate doing the calculations.

\section{RESULTS AND DISCUSSION}

Consider a hypothetical copper deposit where grades of the orebody are equally distributed throughout the pit and a grade block model constructed (Table 2). Three scenarios are considered on which the amount of acid producing waste rock is estimated to be $0,8 \%$ and $15 \%$ and the amount of acid producing tailings is estimated to be $0,15 \%$ and $8 \%$ percent, respectively (Table 3).

The associated capacities, costs, price and recovery are:

Capacities:

$\mathrm{M}=100 \mathrm{t} / \mathrm{y} ; \mathrm{C}=50 \mathrm{t} / \mathrm{y} ; \mathrm{R}=40 \mathrm{lbs} / \mathrm{y} ;$

Costs:

$\mathrm{m}=1.0 \$ / \mathrm{t}$

$$
\mathrm{a}=0.15 \$ / \mathrm{t}
$$$$
\mathrm{b}=0.50 \$ / \mathrm{t}
$$

$c=2.0 \$ / t$

$\mathrm{u}=0.25 \$ / \mathrm{t}$

$\mathrm{v}=0.75 \$ / \mathrm{t}$

$\mathrm{r}=5.0 \$ / \mathrm{lb}$

$\mathrm{f}=300.0 \$ / \mathrm{t}$

Copper price:

$25.0 \$ / l b$

Recovery (Yield):

$\mathrm{y}=1.0(100 \%$ recovery is assumed $)$

Tables 4, 5 and 6 show the results of the scenarios 1, 2 and 3 , respectively.

By comparison the results of the scenarios, one can see that the NPV of scenarios 2 and 3 are considerably higher than that of the first scenario, because all environmental costs were considered during the mine planning. In scenario 1 , future value of the closure/cleanup costs for neutralization of acid 
producing tailings and acid producing waste materials in the basis of present value are considered to be $0.81 \$ / t$ and $0.54 \$ / t$ respectively that causes decrease the NPV from \$1203.29 to \$ 635.32. Using this method, the life of the deposit will remain constant.

Table 2: Grade tonnage distribution of the orebody

\begin{tabular}{ll}
\hline Grade (\%) & Quantity (t) \\
\hline $0.0-0.1$ & 100 \\
$0.1-0.2$ & 100 \\
$0.2-0.3$ & 100 \\
$0.3-0.4$ & 100 \\
$0.4-0.5$ & 100 \\
$0.5-0.6$ & 100 \\
$0.6-0.7$ & 100 \\
$0.7-0.8$ & 100 \\
$0.8-0.9$ & 100 \\
$0.9-1.0$ & 100 \\
Total & 1000 \\
\hline
\end{tabular}

The common mining cycle utilized to make calculations about cut off grades generally considers the following variables: mining cost, treating cost, refinery cost, sales and overhead costs, the price of the metal or mineral and the recovery of that metal or mineral after processing.

A missing part of these calculations is environmental extra costs specially contaminated waste/tailings disposal costs that are not considered directly into the cut off grade calculations. This aspect causes differences in the profitability of the ore deposit, which can vary significantly from the conceptual stage of the mine project to the post mining stage.

A developed environmental-oriented model for optimum cut off grades in open pit mining projects presented in this paper with the concept of elimination or mitigation the waste/tailings and pollution in the original place to minimize AMD.

Table 3: Scenarios of a hypothetical deposit

\begin{tabular}{lllll}
\hline AP/NA & Unit & Scenario 1 & Scenario 2 & Scenario 3 \\
\hline A & $\%$ & 1.00 & 0.92 & 0.85 \\
B & $\%$ & 0.00 & 0.08 & 0.15 \\
U & $\%$ & 1.00 & 0.85 & 0.92 \\
V & $\%$ & 0.00 & 0.15 & 0.08 \\
\hline
\end{tabular}

Table 4: Optimum cut off grade policy for scenario 1

\begin{tabular}{lclllllllll}
\hline & T (ore+waste) & Gopt & $\mathrm{g}$ & Qm & Qc & Qr & Life & PPY & NPV & NPV:PPY \\
\hline Year 1 & $1,000.00$ & 0.50 & 0.75 & 100.00 & 50.00 & 37.50 & 10.00 & 239.38 & $1,201.37$ & 208.15 \\
Year 2 & 900.00 & 0.50 & 0.75 & 100.00 & 50.00 & 37.50 & 9.00 & 239.38 & $1,142.20$ & 389.15 \\
Year 3 & 800.00 & 0.50 & 0.75 & 100.00 & 50.00 & 37.50 & 8.00 & 239.38 & $1,074.15$ & 546.55 \\
Year 4 & 700.00 & 0.50 & 0.75 & 100.00 & 50.00 & 37.50 & 7.00 & 239.38 & 995.90 & 683.41 \\
Year 5 & 600.00 & 0.50 & 0.75 & 100.00 & 50.00 & 37.50 & 6.00 & 239.38 & 905.91 & 802.42 \\
Year 6 & 500.00 & 0.50 & 0.75 & 100.00 & 50.00 & 37.50 & 5.00 & 239.38 & 802.42 & 905.91 \\
Year 7 & 400.00 & 0.50 & 0.75 & 100.00 & 50.00 & 37.50 & 4.00 & 239.38 & 683.41 & 995.90 \\
Year 8 & 300.00 & 0.48 & 0.74 & 96.30 & 50.00 & 36.92 & 3.12 & 231.83 & 545.54 & $1,071.69$ \\
Year 9 & 203.70 & 0.46 & 0.73 & 92.44 & 50.00 & 36.39 & 2.20 & 225.53 & 398.55 & $1,135.80$ \\
Year 10 & 111.26 & 0.40 & 0.70 & 83.33 & 50.00 & 34.94 & 1.34 & 206.77 & 234.64 & $1,186.91$ \\
Year 11 & 27.92 & 0.40 & 0.70 & 27.92 & 16.75 & 11.71 & 0.31 & 76.22 & 21.68 & $1,203.29$ \\
Year 12 & & & & & & & & -567.97 & & 635.32 \\
Total & & & & $1,000.00$ & 516.75 & 382.46 & & & & \\
\hline
\end{tabular}


F. Rashidinejad et al.

Table 5: Optimum cut off grade policy for scenario 2

\begin{tabular}{|c|c|c|c|c|c|c|c|c|c|c|}
\hline & $\mathrm{T}$ (ore+ waste) & Gopt & g & $\mathrm{Qm}$ & Qc & $\mathrm{Qr}$ & Life & PPY & NPV & NPV:PPY \\
\hline Year 1 & $1,000.00$ & 0.50 & 0.75 & 100.00 & 50.00 & 37.50 & 10.00 & 237.04 & $1,189.64$ & 206.12 \\
\hline Year 2 & 900.00 & 0.50 & 0.75 & 100.00 & 50.00 & 37.50 & 9.00 & 237.04 & $1,131.04$ & 385.35 \\
\hline Year 3 & 800.00 & 0.50 & 0.75 & 100.00 & 50.00 & 37.50 & 8.00 & 237.04 & $1,063.66$ & 541.21 \\
\hline Year 4 & 700.00 & 0.50 & 0.75 & 100.00 & 50.00 & 37.50 & 7.00 & 237.04 & 986.18 & 676.74 \\
\hline Year 5 & 600.00 & 0.50 & 0.75 & 100.00 & 50.00 & 37.50 & 6.00 & 237.04 & 897.06 & 794.59 \\
\hline Year 6 & 500.00 & 0.50 & 0.75 & 100.00 & 50.00 & 37.50 & 5.00 & 237.04 & 794.59 & 897.06 \\
\hline Year 7 & 400.00 & 0.50 & 0.75 & 100.00 & 50.00 & 37.50 & 4.00 & 237.04 & 676.74 & 986.18 \\
\hline Year 8 & 300.00 & 0.48 & 0.74 & 96.26 & 50.00 & 36.91 & 3.12 & 229.49 & 540.23 & $1,061.19$ \\
\hline Year 9 & 203.74 & 0.46 & 0.73 & 92.45 & 50.00 & 36.39 & 2.20 & 223.34 & 394.71 & $1,124.68$ \\
\hline Year 10 & 111.29 & 0.40 & 0.70 & 83.45 & 50.00 & 34.96 & 1.33 & 204.98 & 232.39 & $1,175.35$ \\
\hline Year 11 & 27.84 & 0.40 & 0.70 & 27.84 & 16.68 & 11.67 & 0.31 & 75.03 & 21.31 & $1,191.48$ \\
\hline Year 12 & & & & & & & & 0.00 & & $1,191.48$ \\
\hline Total & & & & $1,000.00$ & 516.68 & 382.43 & & & & \\
\hline
\end{tabular}

Table 6. Optimum cut off grade policy for scenario 3

\begin{tabular}{lllllllllll}
\hline & T (ore+waste) & Gopt & $\mathrm{g}$ & Qm & Qc & Qr & Life & PPY & NPV & NPV:PPY \\
\hline Year 1 & $1,000.00$ & 0.50 & 0.75 & 100.00 & 50.00 & 37.50 & 10.00 & 236.25 & $1,185.68$ & 205.43 \\
Year 2 & 900.00 & 0.50 & 0.75 & 100.00 & 50.00 & 37.50 & 9.00 & 236.25 & $1,127.29$ & 384.07 \\
Year 3 & 800.00 & 0.50 & 0.75 & 100.00 & 50.00 & 37.50 & 8.00 & 236.25 & $1,060.13$ & 539.41 \\
Year 4 & 700.00 & 0.50 & 0.75 & 100.00 & 50.00 & 37.50 & 7.00 & 236.25 & 982.90 & 674.49 \\
Year 5 & 600.00 & 0.50 & 0.75 & 100.00 & 50.00 & 37.50 & 6.00 & 236.25 & 894.08 & 791.95 \\
Year 6 & 500.00 & 0.50 & 0.75 & 100.00 & 50.00 & 37.50 & 5.00 & 236.25 & 791.95 & 894.08 \\
Year 7 & 400.00 & 0.50 & 0.75 & 99.77 & 50.00 & 37.50 & 4.01 & 236.53 & 676.44 & 983.00 \\
Year 8 & 300.23 & 0.48 & 0.74 & 95.85 & 50.00 & 36.86 & 3.13 & 228.20 & 539.37 & $1,057.60$ \\
Year 9 & 204.38 & 0.46 & 0.73 & 92.09 & 50.00 & 36.34 & 2.22 & 222.17 & 395.00 & $1,120.75$ \\
Year 10 & 112.29 & 0.40 & 0.70 & 83.14 & 50.00 & 34.91 & 1.35 & 203.95 & 233.90 & $1,171.17$ \\
Year 11 & 29.16 & 0.40 & 0.70 & 29.16 & 17.53 & 12.24 & 0.31 & 82.91 & 23.64 \\
Year 12 & & & & & & & & 0.00 & $1,188.99$ \\
Total & & & & $1,000.00$ & 517.53 & 382.84 & & & $1,188.99$ \\
\hline
\end{tabular}

Four coefficients that discriminate between acid producing and non acid generating waste materials and tailings incorporated into the Lane's model to ensure optimality of cut off grade calculations. The concept beyond this model does not assure avoiding the AMD generation, but applying it in the mining design and planning will considerably reduce the AMD problems.

\section{REFERENCES}

Asad, M.W.A., (2005). Cutoff grade optimization algorithm for open pit mining operations with consideration of dynamic metal price and cost escalation during mine life,

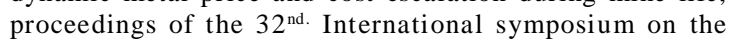

application of computers and operations research in the mineral industry (APCOM), 273-277.

Baird, B. K.; Satchwell, P. C., (2001). Application of economic parameters and cut-offs during and after pit optimization, Min. eng-Littleton, SME, 33-40.

Camus, J. P., (2002). Management of mineral resources: creating value in the mining business, SME, Littleton

Cross, C., (2005). A Rio Tinto view of collaborative research in Europe and the World, Research co-operation in mining, presentation, $16^{\text {th. }}$ Society of Mining Professors (SOMP) annual general meeting, Ankara, Turkey.

Dagdelen, K.; Kawahata, K., (2007). Cut-off grade optimization for large scale multi-mine, multi-process mining operations, Proceedings of the $16^{\text {th. }}$ International symposium on mine planning and equipment selection (MPES) and the $10^{\text {th. }}$ International symposium on 
environmental issues and waste management in energy and mineral production (SWEMP), Held Jointly in Bangkok, Thailand, 226-233.

Deissmann, G.; Kistinger, S.; Kirkaldy, J. L.; Pettit, C. M., (2000). Predictive geochemical modelling of long-term environmental impacts from waste rocks, proceedings of the $5^{\text {th. }}$ International conference on acid rock drainage (ICARD), Vol. 1, Chapter 6, Risk assessment and associated tools, 743-750.

Ding, B.; Pelley, C. W.; de Ruiter, H., (2007). Defining the production scale of an underground mine, Int. J. Mine. Resour. Eng., 12 (1), 1-19.

Ersan, H. Y.; Dagdelen, K.; Rozgonyi, T. G., (2003). Environmental issues and eco-based mine planning, $1^{\text {st. }}$ International mining congress and exhibition of TurkeyIMCET, 11-16.

Hitzman, M. W., (2005). (R)evolution in mining implications for exploration, Min. Eng-Littleton., SME, 57 (1), 30-33.

Hustrulid, W., Kuchta, M., (1995). Open pit mine planning and design, Vol. 1 - Fundamentals, A. A. Balkema, Rotterdom, Brookfield.

James, P. M., (1999). The miner and sustainable development, Min. Eng-Littleton, SME, 89-92.

Krige, D. G., (1987). Elementary geostatistical models applied in forecasting South Afrrica's long-term gold production, Min. eng-Littleton, SME, 427-432.

Lane, K. F., (1964). Choosing the optimum cut-off grades, Colorado school of mines quarterly, 59, 811-824.

Lane, K. F., (1988). The economic definition of Ore, Cutoff grades in theory and practice, Mine. J. Books Ltd., London.

Lee Bullock, R., (2001). General planning of the non-coal underground mine, in underground mining methods, engineering fundamentals and international case studies, Hustrulid, W. A.; Lee Bullock, R., Eds., SME, Littleton.

Lottermoser, B. G., (2003). Mine wastes: characterization, treatment, and environmental impacts, Springer publication.

Minnitt, R. C. A, (2003). Cut-off grade determination for the maximum value of a small Wits-type gold mining operation, Proceedings of the $31^{\text {st. }}$ International symposium on application of computers and operations research in the minerals industries (APCOM), 415-422.

Odell, C. J.; Scoble, M., (2005). Tools for the integration of sustainability into the mine design process, Proceedings of the $32^{\text {nd. }}$ International symposium on the application of computers and operations research in the mineral industry (APCOM), 125-131.

Osanloo, M.; Ataei. M., (2003). Using equivalent grade factors to find the optimum cut off grades of multiple metal deposits, Mine. Eng., 16 (8), 771-776.

Parameswaran, K., (2005). Chapter 3.2, Mine closure planning: reclamation, closure and post-closure issues, Sustainable mining practices-a global prospective, Rajaram, V.; Dutta, S.; Parameswaran, K., Eds., Taylor and Francis, London.
Parsons, A. S.; Hume, H. R., (1997). The contribution of new technology to improved environmental performance in the mining industry, UNEP industry and environment, 38-43.

Rashidinejad, F., (2004). Sungun copper project environmental impact assessment, Proceedings of the $8^{\text {th. }}$ International symposium on environmental issues and waste management in energy and mineral production (SWEMP), Held in Antalya, Turkey 133-138.

Rashidinejad, F.; Osanloo, M.; Rezai, B.; Asi, B., (2007). A prototype holistic cut-off grade model for porphyry coppers, Proceedings of the $16^{\text {th. }}$ International symposium on mine planning and equipment selection (MPES) and the $10^{\text {th. }}$ International symposium on environmental issues and waste management in energy and mineral production (SWEMP), Held Jointly in Bangkok, Thailand, 930-944.

Rashidinejad, F.; Raouf Sheibani, F., (2004). Tailings disposal options study at Sungun copper mine, Proceedings of the $13^{\text {th. }}$ International symposium on mine planning and equipment selection (MPES), Held in Wroclaw, Poland. 857-862.

Ricca, V. T., Chow, K., (1974), Acid Mine Drainage quantity and quality generation model, AIME, Transaction 256, 328-336.

Scoble, M.; Klein B.; Scott Dunbar, W., (2000). Mining waste: Transforming mining systems for waste management, Proceedings of the $6^{\text {th. }}$ International conference on environmental issues and management of waste in energy and mineral production (SWEMP), 333340 .

Shay, D. A.; Cellan, R. R., (2000). Sulfide waste management considerations at Homestake's Santa Fe mine, In proceedings of the $5^{\text {th. }}$ International conference on acid rock drainage (ICARD), Vol. 2, Chapter 8 - Semi-Arid Mine, Waste issues, 1291-1297.

Wheeler, A. J.; Rodrigues, R. L., (2002). Cut off grade analysis at Fazenda Brasileiro: mine planning for declining gold prices, Mining Technology: IMM Transactions section A, 111 (1), 35-46.

WCED, (1987). World Commission on Environment and Development, Our Common Future, Oxford University Press, Oxford

Zhang, S., (1998). Multi-metal recoverable reserve estimation and its impact on the cove ultimate pit design, Mine. Eng., SME, 73-79. 


\section{AUTHOR (S) BIOSKETCHES}

Rashidinejad, F., Adjunct professor in the Department of Mining Engineering, Technical and Engineering

Faculty, Islamic Azad University, Sciences and Research Campus, Tehran, Iran.

Email: frashidinejad@hotmail.com

Osanloo, M., Professor in the Department of Mining, Metallurgical and Petroleum Engineering, Amirkabir

University of Technology, Tehran, Iran. Email: morteza.osanloo@gmail.com

Rezai, B., Professor in the Department of Mining, Metallurgical and Petroleum Engineering, Amirkabir University of Technology, Tehran, Iran. Email: brezai1@yahoo.com

This article should be referenced as follows:

Rashidinejad, F.; Osanloo, M.; Rezai, B., (2008). An environmental oriented model for optimum cut off grades in open pit mining projects to minimize acid mine drainage. Int. J. Environ. Sci. Tech., 5 (2), 183-194. 